\title{
Characterization of the mating-type genes in Leptographium procerum
}

\section{and Leptographium profanum}

Tuan A. Duong $^{1 *}$, Z. Wilhelm de Beer ${ }^{2}$, Brenda D. Wingfield ${ }^{1}$ and Michael J. Wingfield ${ }^{1}$

${ }^{1}$ Department of Genetics, ${ }^{2}$ Department of Microbiology and Plant Pathology, Forestry and Agricultural Biotechnology Institute (FABI), University of Pretoria, Pretoria 0002, South Africa.

* Corresponding author. Phone number: +27 (12) 420-3938; Fax: +27 (12) 420-3960; E-mail address: tuan.duong@fabi.up.ac.za (T.A. Duong); Postal address: Forestry and Agricultural Biotechnology Institute (FABI), University of Pretoria, Pretoria 0002, South Africa.

\section{Highlights}

- The mating-type loci in Leptographium procerum and L. profanum were characterized.

- The PCR-based mating-type markers were developed for these two species.

- Leptographium procerum and L. profanum had a heterothallic mating system and thus these species are heterothallic.

- Cryptic sexual reproduction was suggested for a population of $L$. procerum.

\begin{abstract}
Leptographium procerum and the closely related species Leptographium profanum, are ascomycetes associated with root-infesting beetles on pines and hardwood trees, respectively. Both species occur in North America where they are apparently native. Leptographium procerum has also been found in Europe, China New Zealand, and South Africa where it has most probably been introduced. As is true for many other Leptographium species, sexual states
\end{abstract}


have never been observed in L. procerum or L. profanum. The objectives of this study were to clone and characterize the mating type loci of these fungi, and to develop markers to determine the mating types of individual isolates. To achieve this, a partial sequence of MAT1-2-1 was amplified using degenerate primers targeting the high mobility group (HMG) sequence. A complete MAT1-2 idiomorph of $L$. profanum was subsequently obtained by screening a genomic library using the HMG sequence as a probe. Long range PCR was used to amplify the complete MAT1-1 idiomorph of L. profanum and both the MAT1-1 and MAT1-2 idiomorphs of $L$. procerum. Characterization of the $M A T$ idiomorphs suggests that the $M A T$ genes are fully functional and that individuals of both these species are self-sterile in nature with a heterothallic mating system. Mating type markers were developed and tested on a population of $L$. procerum isolates from the USA, the assumed center of origin for this species. The results suggest that cryptic sexual reproduction is occurring or has recently taken place within this population.

Keywords: Cryptic sex, heterothallic, homothallic, Leptographium procerum, Leptogrpahium profanum, MAT locus.

\section{Introduction}

Sexual reproduction in ascomycetes is governed by the mating type genes residing at the mating type locus (MAT-1) (Turgeon and Yoder 2000; Yoder et al. 1986). Although they occupy the same position in the genome, different mating type alleles have highly dissimilar sequences and gene contents and they are consequently referred to as idiomorphs named MATI-1 and MAT1-2 (Metzenberg and Glass 1990; Turgeon and Yoder 2000). In heterothallic filamentous 
ascomycetes, individual isolates contain either the MAT1-1 or the MAT1-2 idiomorph and sexual reproduction occurs only when isolates containing different $M A T$ idiomorphs interact.

The MAT1-1 idiomorph has one to three genes, including the mandatory MAT1-1-1 encoding a protein that contains alpha box sequences, together with one or a combination of the MAT1-1-2, MAT1-1-3, MAT1-1-4 and MAT1-1-5 genes (Amselem et al. 2011; Coppin et al. 1997; Kronstad and Staben 1997; Turgeon 1998; Turgeon and Yoder 2000). MAT1-2 usually contains a single MAT1-2-1 gene encoding for a protein with a high mobility group (HMG) domain (Coppin et al. 1997; Turgeon and Yoder 2000), but in some cases a second gene (mat a-2, MAT1-2-2; MAT12-3 or MAT1-2-4) can be found within the MAT1-2 idiomorph (Amselem et al. 2011; Kanamori et al. 2007; Martin et al. 2011; Pöggeler and Kück 2000). In contrast to heterothallic fungi, isolates of homothallic species harbor both MAT1-1 and MAT1-2 regions in their genomes, and sexual reproduction can occur in the absence of a second isolate (Nelson 1996). However, there are rare exceptions to this scheme, such as in the case of the homothallic Lodderomyces elongisporus and Neurospora africana, where both $M A T$ idiomorphs are missing in the former species and only MAT1-1 (mat A) is present in the latter species (Butler et al. 2009; Glass and Smith 1994).

The rapidly growing number of studies on fungal mating systems emphasizes the important role that they play in fungal biology. Information regarding structure and organization of $M A T$ genes can be used to establish whether a fungal species reproduces in a homothallic or heterothallic fashion. Furthermore, such knowledge can be used to develop molecular markers in order to determine the mating types of isolates, replacing the laborious and time consuming process of developing and crossing mating tester strains (Brewer et al. 2011; Ramirez-Prado et al. 2008; Scherrer et al. 2005; Steenkamp et al. 2000). The ability to identify mating types using molecular 
markers is also useful when it is necessary to select isolates of opposite mating type for genetic experiments, and this facilitates the discovery of sexual states of species known only by their asexual morphs (Kück and Pöggeler 2009).

The high level of variation in mating type genes offers considerable potential to resolve questions regarding phylogenetic relatedness in species complexes (O'Donnell et al. 2004; Turgeon 1998). Furthermore, information relating to the mating type genes has been used to develop hypotheses relating to the evolution of sexuality and the origins of homothallism and heterothallism in fungi (Butler et al. 2009; Fraser and Heitman 2004; Nygren et al. 2011; Yun et al. 1999). The frequency and distribution of different mating types has also been used to assess sexual reproduction and the preferred mode of reproduction in natural populations (Groenewald et al. 2006; Linde et al. 2003; Rau et al. 2005; Stergiopoulos et al. 2007).

Leptographium procerum and the closely related species, L. profanum, are ascomycetes associated with root-infesting beetles on pine and hardwood trees respectively (Jacobs et al. 2006). While there is no evidence that $L$. profanum is a pathogen, $L$. procerum has been associated with root and root collar diseases of pine in the Eastern United States (Wingfield et al. 1988; Wingfield 1986). Both species are apparently native to North America, and L. profanum is a little-known species that has not been found outside the USA (Jacobs et al. 2006). In contrast, L. procerum, is a very well-known species that has apparently been introduced into various countries including those in Europe, New Zealand, and South Africa (Jacobs and Wingfield 2001; Linnakoski et al. 2012). The most recent introduction of $L$. procerum has been into China where the fungus has apparently contributed to the death of thousands of native Pinus tabuliformis trees (Lu et al. 2009a; Lu et al. 2009b). 
Sexual states of Leptographium species have traditionally been treated in the genus Grosmannia (Zipfel et al. 2006). De Beer et al. (2013) showed that the generic delineation of the two genera is problematic based on currently available data, and that comprehensive multigene phylogenies will be necessary to resolve this question. In view of the discontinuation of the dual nomenclature system (Hawksworth 2011), De Beer et al. (2013) suggested that all 34 Grosmannia species be treated in Leptographium sensu lato, but to avoid unnecessary name changes (Wingfield et al. 2012), current species names in the two genera should be maintained until the generic boundaries have been resolved. At present, 59 of the 93 species in Leptographium sensu lato, including L. procerum or L. profanum, are known only by their asexual states (De Beer and Wingfield 2013). This is despite substantial effort to search for a sexual state in L. procerum (M.J. Wingfield, unpublished). Both $L$. procerum and L. profanum are thus considered mitosporic species.

Based on the consistent absence of observed sexual states in L. procerum and L. profanum, we have hypothesized that both fungi have heterothallic mating type systems. The aims of this study were to test this hypothesis by cloning and characterizing the mating type idiomorphs of $L$. procerum and L. profanum and to develop mating type markers for both species. A further aim was to investigate the mating type frequency in a population of $L$. procerum isolates that might provide evidence of sexual recombination in nature.

\section{Materials and methods}

\subsection{Fungal isolates}

Isolates of L. procerum and L. profanum (Table 1) used for cloning of mating type genes were obtained from the Culture Collection (CMW) of the Forestry and Agricultural Biotechnology 
Institute (FABI), University of Pretoria, South Africa. Isolates of L. procerum used to assess the mating type ratio in a natural population of the fungus were collected in the eastern USA during October of 2009 and have been preserved in CMW.

Table 1 - Fungal isolates used in this study

\begin{tabular}{|c|c|c|c|c|c|}
\hline \multirow[t]{2}{*}{ Species } & \multicolumn{2}{|c|}{ Isolate number } & \multirow[t]{2}{*}{ Host } & \multirow[t]{2}{*}{ Origin } & \multirow{2}{*}{$\begin{array}{l}\text { Mating } \\
\text { type }\end{array}$} \\
\hline & ${ }^{\mathrm{a}} \mathbf{C M W}$ & ${ }^{\mathrm{b}} \mathrm{CBS}$ & & & \\
\hline \multirow[t]{8}{*}{ L. procerum } & 10 & & Pinus nigra & Unknown & MAT1-1 \\
\hline & 12 & 118578 & P. strobus & Farmington, USA & MAT1-1 \\
\hline & 13 & 115211 & Unknown & Unknown & MAT1-1 \\
\hline & 45 & 118580 & P. sylvestris & Minnesota, USA & $M A T 1-2$ \\
\hline & 216 & & P. taeda & Sabie, South Africa & MAT1-1 \\
\hline & 10216 & & P. strobus & Burlington, USA & $M A T 1-1$ \\
\hline & 25627 & & P. tabuliformis & Shanxi, China & MAT1-1 \\
\hline & $\begin{array}{l}\text { Isolates } \\
\text { collecte }\end{array}$ & $\begin{array}{l}\text { proceru } \\
\text { the easter }\end{array}$ & $\begin{array}{l}\text { used for assessment of the mat } \\
\text { USA during } 2009 .\end{array}$ & $\mathrm{g}$ type ratio in a natur & ulation were \\
\hline \multirow[t]{5}{*}{ L. profanum } & 10550 & & Dogwood & USA & MAT1-2 \\
\hline & 10552 & 120307 & Hickory & USA & MAT1-2 \\
\hline & 10553 & & Hickory & USA & $M A T 1-2$ \\
\hline & 10554 & 120226 & Nyssa sylvatica (Blackgum) & USA & MAT1-1 \\
\hline & 10555 & & N. sylvatica (Blackgum) & USA & MAT1-1 \\
\hline
\end{tabular}

${ }^{\mathrm{a}} \mathrm{CMW}=$ Culture Collection of the Forestry and Agricultural Biotechnology Institute (FABI), University of Pretoria, South Africa.

${ }^{\mathrm{b}} \mathrm{CBS}=$ Centraalbureau voor Schimmelcultures, Utrecht, The Netherlands

\subsection{DNA isolation}

Fungal mycelium was grown in liquid medium containing $2 \%$ malt extract and $0.2 \%$ yeast extract (YM broth) for 3-5 days. Mycelium was harvested by centrifugation and lyophilized. DNA was isolated from the lyophilized mycelium using the method described by Aljanabi and Martinez (1997) with minor modifications. After extraction, DNA was resuspended in $200 \mu$ of TE buffer (10 mM Tris-HCl, 1 mM EDTA, pH 8.0) containing $0.02 \mathrm{mg} / \mathrm{ml}$ of RNase A. After 30 minutes incubation at $37{ }^{\circ} \mathrm{C}$, samples were extracted twice with an equal volume of Phenol/Chloroform/Isoamyl Alcohol (25:24:1, v/v). DNA was then precipitated from the solution by adding $1 / 10$ volume of $3 \mathrm{M}$ sodium acetate and 2.5 volume of absolute ethanol. 
Samples were incubated at $-20^{\circ} \mathrm{C}$ for $1 \mathrm{~h}$ and then centrifuged at $10000 \mathrm{~g}$ for $30 \mathrm{~min}$ at $4{ }^{\circ} \mathrm{C}$. The pellets were washed twice with 70\% ethanol, air dried and resuspended in Tris-HCl $10 \mathrm{mM}$, $\mathrm{pH}$ 8.0. This DNA was used for Southern analyses and long range PCR. DNA samples used for PCR detection of mating-type genes were prepared from fresh mycelium using PrepMan ${ }^{\mathrm{TM}}$ Ultra reagent (Applied Biosystems, California, USA) following the protocol suggested by the manufacturer.

\subsection{Cloning the mating-type idiomorphs from L. profanum}

\subsubsection{Cloning of MAT1-2 in L. profanum}

Degenerate primers NcHMG1 and NcHMG2 (Arie et al. 1997) were used to obtain partial sequence of HMG-box of MAT 1-2-1 in L. profanum. The PCR mixture, $25 \mu 1$ total volume, consisted of $2.5 \mu 110 \times$ PCR reaction buffer, $2.5 \mathrm{mM} \mathrm{MgCl}_{2}, 200 \mu \mathrm{M}$ each dNTP, $1 \mu \mathrm{M}$ of each primer, 1 U FastStart Taq DNA Polymerase (Roche Diagnostics GmbH, Mannheim, Germany) and 20 to 50 ng of genomic DNA. PCR reactions were performed in an Eppendorf MasterCycler ${ }^{\circledR}$ gradient (Eppendorf, Hamburg, Germany) using the following conditions: an initial denaturation at $95{ }^{\circ} \mathrm{C}$ for $5 \mathrm{~min}$, followed by 35 cycles of $95{ }^{\circ} \mathrm{C}$ for $30 \mathrm{sec}, 55^{\circ} \mathrm{C}$ annealing for $30 \mathrm{sec}$, and $72{ }^{\circ} \mathrm{C}$ extension for $60 \mathrm{sec}$, with a final extension at $72{ }^{\circ} \mathrm{C}$ for $8 \mathrm{~min}$. Amplified products were separated in a $1.5 \%(w / v)$ agarose gel, stained with GelRed (Biotium, Inc., California, USA) and visualized under UV light. Bands of expected size (approximately $300 \mathrm{bp}$ ), were excised and DNA fragments were recovered from the gel using a QIAquick Gel Extraction Kit (Qiagen, Inc., California, USA). The purified DNA fragments were ligated into pGEM®-T vector (Promega, Wisconsin, USA) and transformed into E. coli JM109. Plasmids were extracted from the positive clones and sequenced using T6 an SP7 primers. 
Specific primers (P-HMG-F: 5'-CTCAACCTGTCGCTTGATTTC-3' and P-HMG-R: 5'TATCGTAAGGACCACCACAAGG-3') were designed from HMG-box sequences of $L$. profanum. These primers were then used to screen a number of $L$. profanum isolates for the presence of MAT1-2-1. The PCR reaction mixture and thermal profile used was the same as that for the degenerate primers NcHMG1 and NcHMG2, except that only $0.2 \mu \mathrm{M}$ of each primer was used. PCR products were separated using agarose gel electrophoresis, stained with GelRed and examined under UV light. Isolates that gave a band around $224 \mathrm{bp}$ were then assigned as representing the MAT1-2 genotype; isolates that did not give an expected product were putatively assigned as representing the MAT1-1 genotype.

Southern blotting was carried out with genomic DNA from two L. profanum MAT1-2 isolates (CMW 10550 and CMW 15002). A DIG-labeled probe was synthesized by using a PCR DIG probe synthesis kit (Roche), following the manufacturer's protocol and using primers P-HMG-F and P-HMG-R, and pGEM ${ }^{\circledR}-\mathrm{T}$ containing the HMG box sequence from L. profanum as template. The genomic DNA was extracted from lyophilized fungal mycelium as described above. Five micrograms of each DNA sample were digested to completion with EcoRI and HindIII (Fermentas, Vilnius, Lithuania). After digestion, DNA fragments were precipitated using ethanol and resuspended in $20 \mu \mathrm{l}$ of TE buffer. The fragments were then separated in a $0.8 \%$ agarose gel. The DIG-labeled DNA molecular weight marker VII (Roche) was used as a size standard for electrophoresis and Southern hybridization. The DNA fragments were transferred from agarose gel onto a Nylon membrane (Roche) using the capillary transfer method, and fixed to the membrane under UV irradiation. This membrane was used for Southern hybridization with the DIG-labeled probes. The hybridization and detection was carried out using reagent from DIGHigh prime DNA labeling and detection kit (Roche) following the manufacturer's protocols. 
Results obtained from Southern blot showed exactly the same pattern for the two L. profanum isolates tested. The $E c o$ RI digested fragments gave a hybridized signal of about $4 \mathrm{~kb}$, while the HindIII digested fragments gave a signal of over $8 \mathrm{~kb}$. A selection was then made to use HindIIIdigested DNA from CMW10552 to construct a partial genomic library for screening of the MAT1-2 idiomorph. Ten micrograms of genomic DNA from CMW10552 was completely digested with HindIII and separated on a $0.8 \%$ agarose gel. Fragments with sizes corresponding to the hybridized signal were excised from the gel and purified using QIAquick gel extraction kit (Qiagen). The fragments were cloned into the pBluescript II KS (+) phagemid vector (Stratagene, California, USA) and transformed into E. coli JM109. This library was then screened for clones harboring MAT1-2 by means of colony hybridization using the same DIGlabeled probe that was used for Southern hybridization. Plasmids from the positive clones were extracted and inserts were sequenced by primer walking (sequencing primers are available on request). Genes present in the inserts were predicted using FGENESH+ (Salamov and Solovyev 2000) (http://linux1.softberry.com). Mating type genes and other Open Reading Frames (ORFs) were identified by BLAST against the NCBI database.

\subsubsection{Cloning of MAT1-1 in L. profanum}

The MAT1-1 idiomorph in L. profanum was obtained using long range PCR with primers PSeq-7 (5'-AGGATGGGAAGGGATTCT -3') and Pseq-8 (5'-CAGACCGGGAGATTGACTC-3') designed from the regions flanking the MAT1-2 idiomorphs. PCR was performed using these primers on a DNA sample of a MAT1-1 isolate as determined based on the absence of PCR product when amplified with primers targeting the MAT1-2 HMG box. The long range PCR mixture, $50 \mu 1$ total volume, consisted of $5 \mu 1$ 10× $\mathrm{PCR}$ reaction buffer with $27.5 \mathrm{mM} \mathrm{MgCl}$, $500 \mu \mathrm{M}$ each dNTP, $0.3 \mu \mathrm{M}$ of each primer, $0.75 \mu \mathrm{l}$ expand long template enzyme mix (Roche 
Applied Science) and $200 \mathrm{ng}$ of genomic DNA. The PCR thermal cycle consisted of an initial denaturation at $95{ }^{\circ} \mathrm{C}$ for $5 \mathrm{~min}$, followed by 10 cycles of $94{ }^{\circ} \mathrm{C}$ for $10 \mathrm{sec}, 53{ }^{\circ} \mathrm{C}$ annealing for $30 \mathrm{sec}$, and $68^{\circ} \mathrm{C}$ extension for $8 \mathrm{~min}$., followed by 25 cycles of $94{ }^{\circ} \mathrm{C}$ for $15 \mathrm{sec}, 55^{\circ} \mathrm{C}$ annealing for $30 \mathrm{sec}$, and $68{ }^{\circ} \mathrm{C}$ extension for $8 \mathrm{~min}$. (plus $20 \mathrm{sec}$. cycle elongation for each successive cycle), and a final extension at $72{ }^{\circ} \mathrm{C}$ for $8 \mathrm{~min}$. Amplified products were separated by agarose gel electrophoresis. Fragments of the expected size were excised from the gel, purified using the QIAGEN gel extraction kit and sequenced by primer walking. Genes were predicted using FGENESH+ (Salamov and Solovyev 2000). MAT genes were identified using the predicted amino acid sequences and BLASTp against the NCBI database.

\subsection{Cloning the mating-type idiomorphs of L. procerum}

The mating type idiomorphs (MAT1-1 and MAT1-2) in L. procerum were obtained by long range PCR using primers PSeq-7 and PSeq-12 (5'-TAGCCGTGGGATGGAGGTTG-3') designed from the flanking regions of the mating type idiomorphs of L. profanum. Various L. procerum isolates were first screened with P-HMG-F and P-HMG-R primers to identify their putative mating type. Genomic DNA from two L. procerum isolates of opposite mating type (CMW 45 as MAT1-2 and CMW 216 as MAT1-1) were used in long range PCR's in order to obtain both MAT1-1 and MAT1-2 idiomorphs. The PCR protocol and thermal cycles used were the same as those used to obtain MAT1-1 in L. profanum as described above. The PCR products were excised from the gel, purified and sequenced as described above. Genes were predicted using FGENESH+ and manually compared with those in L. profanum. 


\subsection{Phylogenetic analyses of the $H M G$ and $\alpha$ domain amino acid sequences}

Deduced amino acid sequences of HMG and $\alpha$ domain were compared to those of other ascomycetes from GenBank using BLASTp search. Representative sequences were downloaded, the dataset was compiled and aligned using an online version of MAFFT 6 (Katoh and Toh 2008). Neighbor joining analyses were performed using MEGA 5.01 (Tamura et al. 2011) with 1000 bootstrap replicates.

\subsection{Development of multiplex PCR-based mating type markers for L. profanum and L. procerum}

The PCR-based mating type markers for L. profanum and L. procerum were developed based on sequences of MAT genes of these species. For detection of the MAT1-2 idiomorph, primers PMAT2-F (5'-CGATGGTGAAGTATGTGATTGA -3') and P-MAT2-R (5'TTCAGCCTCATCGCCAGT-3') were designed from the conserved and unique regions of MAT1-2-1 from both L. profanum and L. procerum. Primers P-MAT1-F (5'ATGGCCGATGAAGACTGCT-3') and P-MAT1-R (5'-CTTCCGAATTTCCTTGGATT-3') were designed from the MAT1-1-3 gene region for both species for the detection of the MAT1-1 idiomorph. All primers were selected to have the same annealing temperature and to result in different amplicon sizes. These primers were combined in a multiplex PCR to detect mating types of isolates of both species. A number of L. profanum and L. procerum isolates (Table 1) were selected to test the amplification success and the specificity of the primers.

The multiplex PCR reaction consisted of $2.5 \mu 110 \times \mathrm{PCR}$ reaction buffer, $2.5 \mathrm{mM} \mathrm{MgCl} 2,200$ $\mu \mathrm{M}$ each dNTP, $0.2 \mu \mathrm{M}$ of each primer (both MAT1-1 and MAT1-2 primers), 1 U FastStart Taq DNA Polymerase (Roche) and 20 to 50 ng of genomic DNA. PCR cycling conditions were an initial denaturation at $95{ }^{\circ} \mathrm{C}$ for $5 \mathrm{~min}$, followed by 35 cycles of $95{ }^{\circ} \mathrm{C}$ for $30 \mathrm{sec}, 55^{\circ} \mathrm{C}$ 
annealing for $30 \mathrm{sec}$, and $72{ }^{\circ} \mathrm{C}$ extension for $60 \mathrm{sec}$, with a final extension at $72{ }^{\circ} \mathrm{C}$ for 8 min. PCR products were separated on a 2\% agarose gel, stained with GelRed and examined under UV light. Isolates presenting a product of $620 \mathrm{bp}$ were designated as MAT1-2, while isolates presenting a product of $273 \mathrm{bp}$ were designated as MAT1-1.

\subsection{Sexual compatibility tests}

Leptographium profanum and L. procerum isolates of opposite mating type as determined by the multiplex PCR were paired in culture in an attempt to induce the formation of teleomorph structures. Four L. profanum isolates (two MAT-1 and two MAT-2) and ten L. procerum isolates (five $M A T-1$ and five $M A T-2)$ were paired in all possible combinations (including both specific and interspecific pairings) on water agar plates containing pine twigs known to stimulate the formation of ascomata in related fungi (authors, unpublished). The plates were incubated at 15 ${ }^{\circ} \mathrm{C}$ and $25^{\circ} \mathrm{C}$ in the dark and examined monthly for one year for the presence of ascomata.

\subsection{Distribution of mating-type genes in a population of L. procerum}

The newly developed primers P-MAT1-F and P-MAT1-R (for MAT1-1) and P-MAT2-F and PMAT2-R (for MAT1-2) were used to investigate the mating type ratio in a population of $L$. procerum. Twenty isolates of $L$. procerum collected during 2009 on native Pinus resinosa and $P$. strobus infested with the bark beetle Dendroctonus valens (Coleoptera: Scolytinae) growing in Pennsylvania, Massachusetts and New Hampshire, USA, were used in this study. DNA extraction was carried out using PrepMan ${ }^{\mathrm{TM}}$ Ultra reagent (Applied Biosystems). The multiplexing PCR mixture and thermal profile used for these primers was as described in section 2.5 above. The mating type of each isolate was assigned based on the size of the corresponding PCR product. 


\section{Results}

\subsection{Cloning the mating-type idiomorphs in L. profanum}

\subsubsection{Cloning of MAT1-2 in L. profanum}

PCR with the degenerate primers NcHMG1 and NcHMG2 yielded expected bands of around 300 bps for isolates of $L$. profanum and L. procerum. The bands were successfully recovered from the gel and cloned in to pGEMT-easy. Sequencing with T7 and SP6 primers confirmed that these are part of the HMG boxes of MAT1-2-1, having high levels of similarity with known MAT1-2-1 sequences of Ophiostoma novo-ulmi and Ophiostoma himal-ulmi (Paoletti et al. 2005). New HMG box specific primers (P-HMG-F and P-HMG-R) were developed and successfully amplified HMG box sequences from L. profanum and L. procerum.

Southern blot analysis of genomic DNA from two L. profanum isolates using the HMG box as probes resulted in similar hybridization patterns and gave a signal at about $4 \mathrm{~kb}$ and over $8 \mathrm{~kb}$ for EcoRI and HindIII digested fragments, respectively. A partial genomic DNA library was constructed for HindIII-digested fragments and colony hybridization resulted in three positive clones in approximately two thousand colonies screened. Sequencing plasmids obtaining from these clones confirmed the presence of a $10.5 \mathrm{~kb}$ insert. Gene prediction using FGENESH+ showed that the insert harbored a complete MAT1-2 idiomorph (GenBank accession number KC883457) consisting of a MAT1-2-1 gene (996 pb in size, predicted ORF of 867 bp) and a truncated version of MAT1-1-1 (1558 bp in size, predicted ORF of $1341 \mathrm{bp}$ ) (Fig 1). The partial sequence of the $S L A$ gene flanking the MAT1-2 idiomorph was also obtained, however neither a DNA lyase gene sequence nor any other open reading frame was found in the other flanking 
region of the MAT1-2 idiomorph. MAT1-2-1 contained a typical HMG box similar to that known

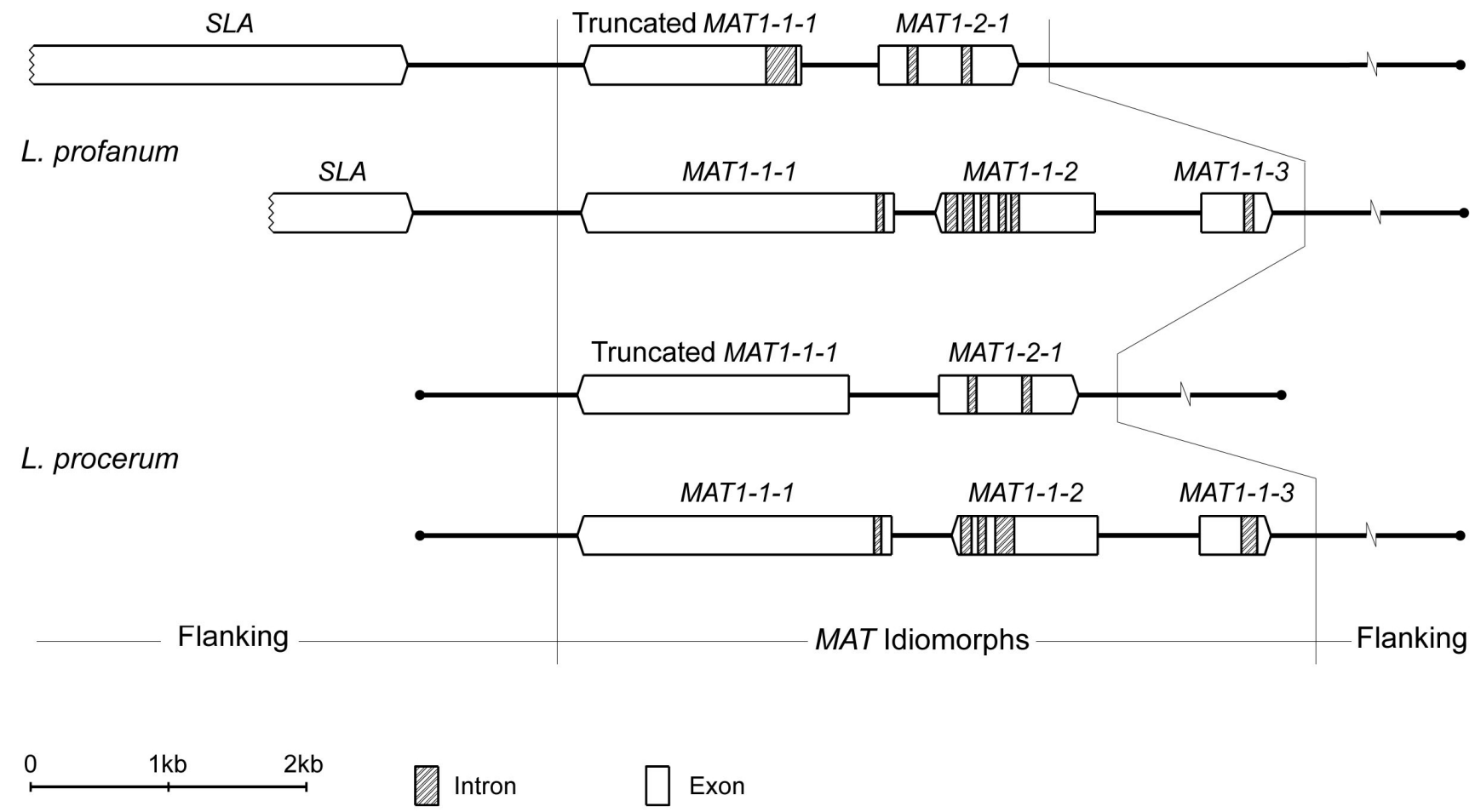

Fig 1 - Organization of the mating type loci of $L$. procerum and $L$. profanum. The introns were predicted using the program FGENESH+ (Salamov and Solovyev 2000) and thus the presence and size of the introns are putative.

in the MAT1-2-1 gene of other ascomycetes and had two introns of 61 and $68 \mathrm{bp}$. The second intron resides within the HMG box and split the codon encoding for serine as is found in many ascomycetes. Alignment of the HMG box DNA and deduced amino acid sequences showed high similarity with sequences from other ascomycetes (Fig 2). BLAST analysis of MAT1-2-1 deduced amino acid sequence showed $75 \%$ and $65 \%$ similarity with the predicted protein sequence of MAT1-2-1 from Grosmannia clavigera (GenBank accession number: ACXQ02000048) and O. himal-ulmi (Paoletti et al. 2005) respectively. A truncated version of 


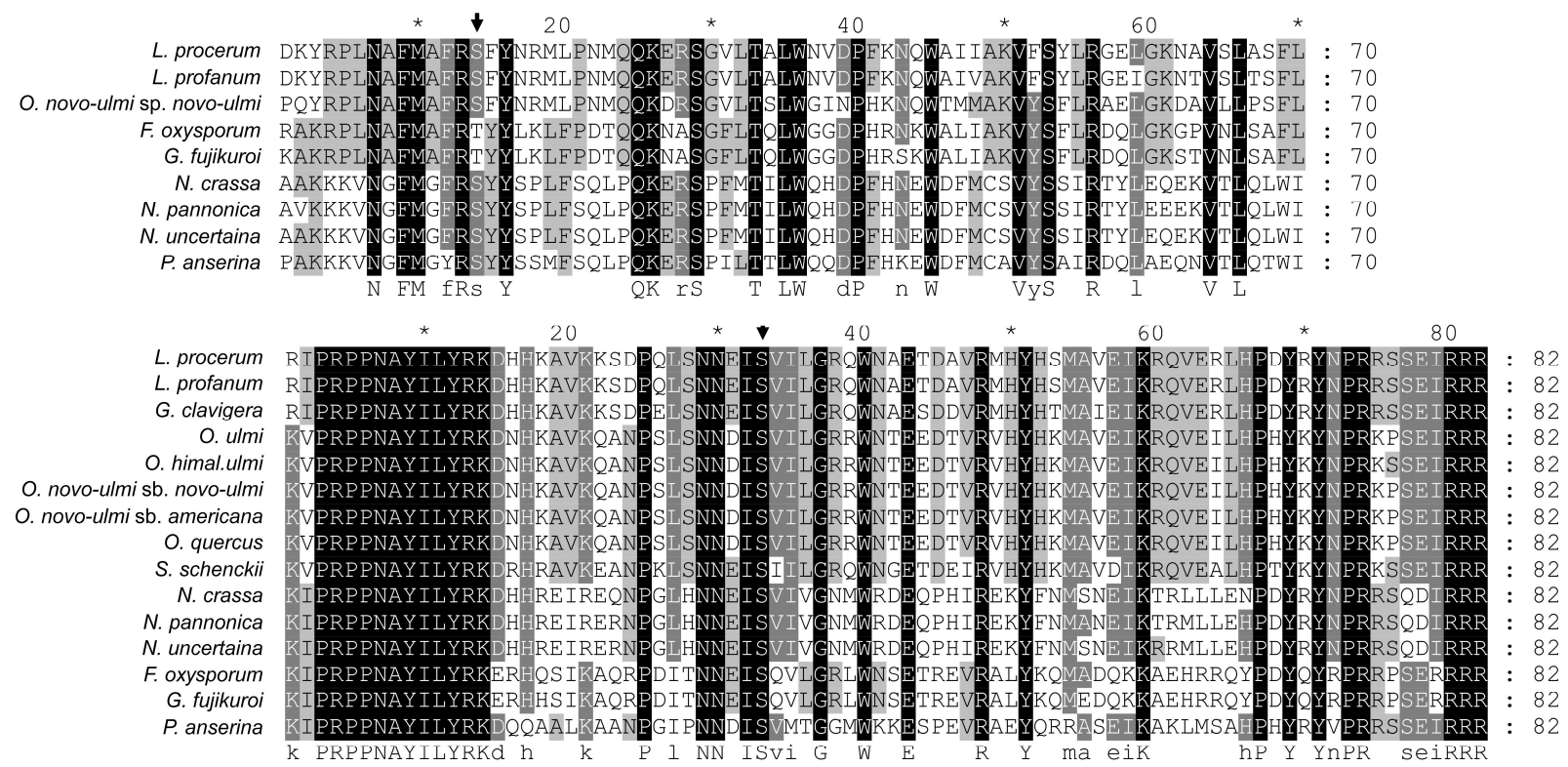

Fig 2 - Alignment of amino acid sequences of the $\alpha$ domain (top) and HMG-box domain (bottom) from $L$.

procerum, L. profanum and other ascomycetes. Black arrows indicate intron positions.

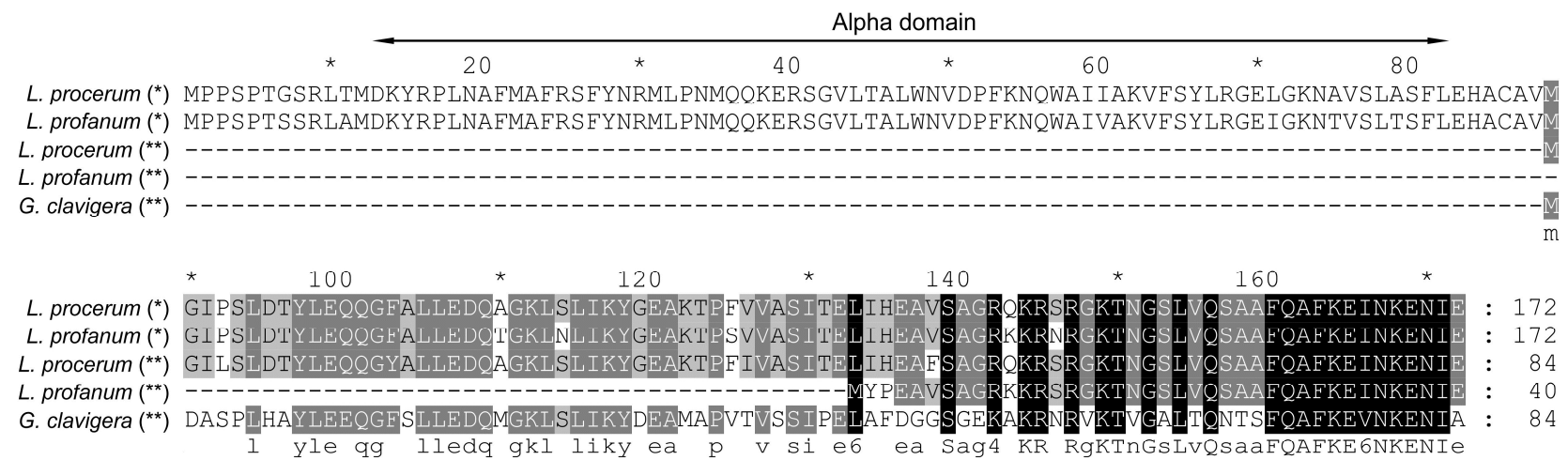

Fig 3 - Alignment of N-terminal amino acid sequences of MAT1-1-1 (*) and truncated MAT1-1-1 (**) from $L$.

procerum, L. profanum and G. clavigera indicating that alpha domain sequences are missing in truncated MAT1-1-1 in all three species.

MAT1-1-1 with a 217 bp intron was also found on the MAT1-2 idiomorph (Fig 1). BLAST analysis of its deduced amino acid sequence showed $36 \%$ similarity to the predicted MAT1-1-1 
gene product from O. novo-ulmi subsp. novo-ulmi. However, sequence analysis showed that the $\alpha$ domain was absent (Fig 3), suggesting that this gene product would not be fully functional.

\subsubsection{Cloning of MAT1-1 in L. profanum}

Long range PCR using primers (PSeq-7 and PSeq-8) flanking the MAT1-2 idiomorph, yielded an expected PCR product of about $9.1 \mathrm{~kb}$ for a L. profanum MATI-1 isolate (CMW10555). Direct sequencing of this PCR product confirmed the presence of a complete MAT1-1 idiomorph (GenBank accession number KC883458). Gene prediction using FGENESH+ and BLAST analysis showed that this fragment contained a partial sequence of the $S L A$ gene and a complete MAT1-1 idiomorph with each of the MAT1-1-1, MAT1-1-2 and MAT1-1-3 genes (Fig 1). No other ORF was found in the fragment. MAT1-1-1 was $2251 \mathrm{bp}$ in length, had one intron of $52 \mathrm{bp}$ and contained a conserved $\alpha$ domain. BLASTp analysis of the MAT1-1-1 protein sequence showed $36 \%$ and $33 \%$ similarity with predicted MAT1-1-1 gene products from Ophiostoma novo-ulmi subsp. novo-ulmi (Jacobi et al. 2010) and O. quercus (Wilken et al. 2012) respectively. Alignment of the $\alpha$ domain nucleotide and amino acid sequences with those of

other ascomycetes showed a high level of similarity (Fig 2). The MAT 1-1-2 gene was $1171 \mathrm{bp}$ in length (predicted ORF of $849 \mathrm{bp}$ ) and contained 5 introns of 84, 76, 56, 50 and $56 \mathrm{bp}$ respectively. BLASTp analysis of the MAT1-1-2 deduced amino acid sequence showed $29 \%$ similarity with the predicted MAT1-1-2 gene product from O. novo-ulmi subsp. novo-ulmi. MAT1-1-3 was $498 \mathrm{bp}$ in length (predicted ORF of $405 \mathrm{bp}$ ) and contained one intron of $93 \mathrm{bp}$. BLASTp analysis of the MAT1-1-3 deduced amino acid sequence showed 44 and $42 \%$ similarity with MAT1-1-3 gene products from $O$. quercus and $O$. novo-ulmi subsp. novo-ulmi respectively. 
The fact that the MAT locus contained either the MAT1-1 or the MAT1-2 idiomorph suggests that L. profanum is a heterothallic species.

\subsection{Cloning the mating-type idiomorphs in L. procerum}

The long range PCR using primers PSeq-7 and PSeq-12 resulted in PCR products of about $7.7 \mathrm{~kb}$ in the L. procerum MAT1-1 isolate (CMW216) and about $6.4 \mathrm{~kb}$ in the L. procerum MAT1-2 isolate (CMW45). Sequences determined for these PCR products confirmed that the MAT1-1 and MAT1-2 idiomorphs from L. procerum had been successfully identified. The gene elements and organization of the MAT1-1 and MAT1-2 idiomorphs in L. procerum were similar to those in $L$. profanum. The MAT1-1 idiomorphs (GenBank accession number KC883456) consisted of MAT1-1-1, MAT1-1-2 and MAT1-1-3 genes (Fig 1) with very high sequence similarity to those in L. profanum. The MAT1-1-1 gene was 2260 bp in size (predicted ORF of 2208 bp) and contained one intron of $52 \mathrm{bp}$. A conserved $\alpha$ domain was detected in the sequence of the MAT1-1-1 gene. The MAT1-1-2 gene was $1040 \mathrm{bp}$ in size (predicted ORF of $771 \mathrm{bp}$ ) and had three introns of 76, 56 and 137 bp. MAT1-1-3 was 498 bp in size (predicted ORF of 384 bp) and contained one intron of 114 bp. The MAT1-2 idiomorphs (GenBank accession number KC883455) consisted of a MAT1-2-1 gene together with a truncated version of a MAT1-1-1 gene (Fig 1). The sequences of these two genes were also very similar to those of L. profanum. The truncated MAT1-1-1 gene lacked an $\alpha$ domain sequence (Fig 3), was 1950 bp in size and had no intron. MAT1-2-1 was 993 bp in size (predicted of ORF 867), contained a conserved HMG-box sequence and had two introns of 60 and $66 \mathrm{bp}$. The gene elements and structures of MAT idiomorphs in L. procerum suggested that this species is heterothallic. 


\subsection{Phylogenetic analyses of the $H M G$ and $\alpha$ domain amino acid sequences}

Phylogenetic trees with the same topology and strongly supported monophyletic clades were obtained from phylogenetic analyses of the HMG and alpha domain amino acid sequence (Fig 4). Similar topologies were also observed when DNA sequences were used (data not shown). The HMG and alpha domain protein sequences of Ophiostomatoid fungi formed a monophyletic clade with strong bootstrap support. Three sub-clades emerged for Leptographium sensu lato, Sporothrix and Ophiostoma also with strong bootstrap support. Well supported clades were also observed for other ascomycetes included in the analyses i.e. the Sordariales, Hypocreales, Capnodiales and Pleosporales (Fig 4).
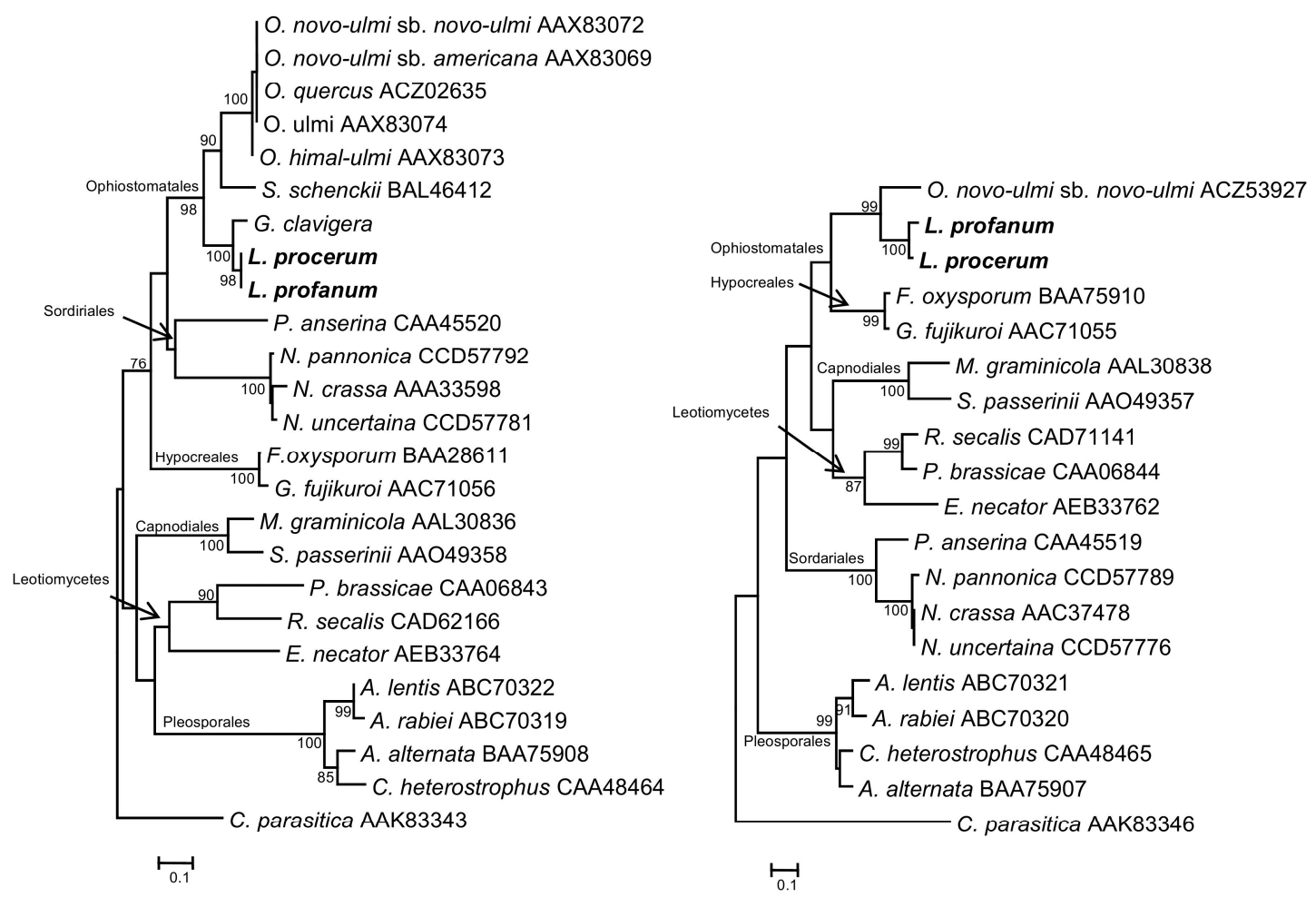

Fig 4 - Neighbor joining trees derived from analysis of the HMG-box domain (left) and $\alpha$ domain (right) amino acid sequences from L. procerum, L. profanum and other ascomycetes. Bootstrap values (1000 replicates) above $75 \%$ are indicated at nodes. GenBank accession numbers are presented after the species name. 


\subsection{Development of multiplex PCR-based mating type markers for L. profanum and L. procerum}

The primer pairs P-MAT1-F, P-MAT1-R, P-MAT2-F and P-MAT2-R consistently amplified the partial MAT1-1 and MAT1-2 idiomorphs from both L. profanum and L. procerum isolates in a multiplex PCR assay. MAT1-1 isolates resulted in a unique band of $273 \mathrm{bp}$, whereas MAT1-2 isolates gave a unique band of $620 \mathrm{bp}$. The different PCR products of the two mating types were differentiated easily using agarose gel electrophoresis (Fig 5).

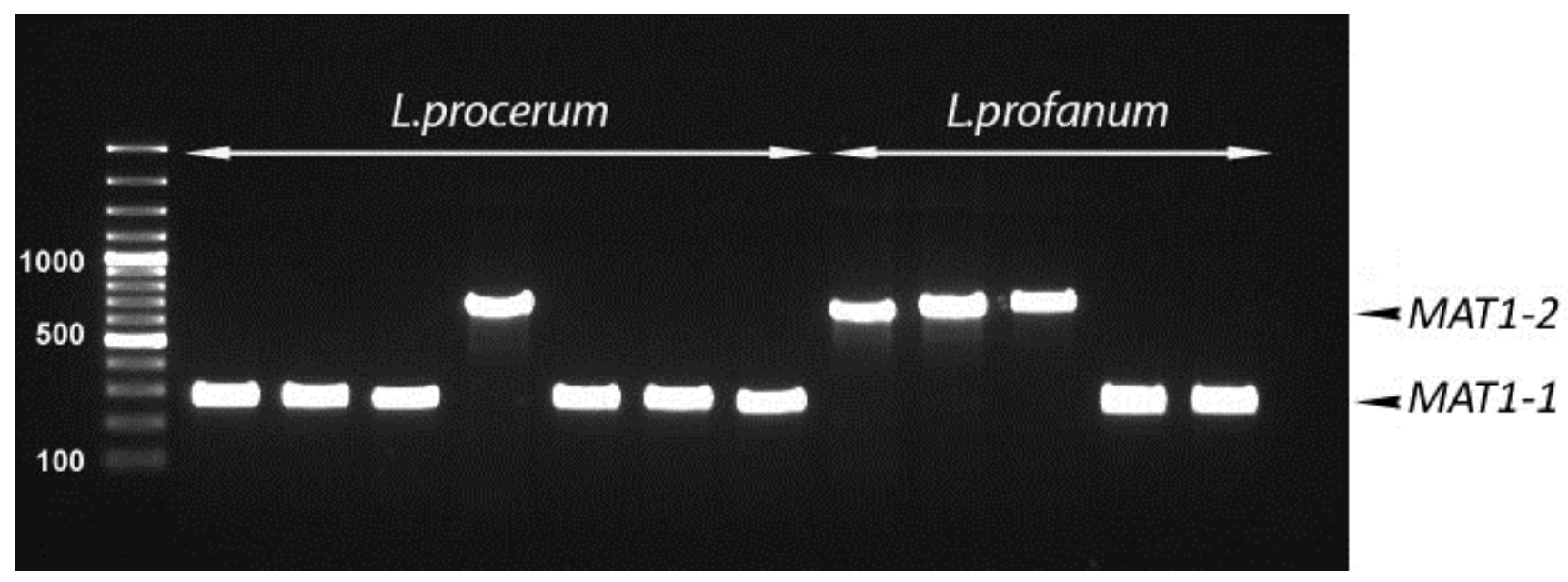

Fig 5 - Results obtained from a multiplex PCR assay to determine the mating genotype of isolates of $L$. procerum and L. profanum. From left to right, DNA samples from L. procerum CMW10; CMW12; CMW13; CMW45; CMW216; CMW10216; CMW25627; and L. profanum CMW10550; CMW10552; CMW10553; CMW10554; CMW10555 were tested. All fragments were separated in 2\% agarose gel, stained with GelRed and visualized under UV light. The molecular weight marker used was GeneRuler ${ }^{\mathrm{TM}} 100$ bp Plus DNA Ladder (Fermentas).

\subsection{Sexual compatibility tests}

The year-long experiment to test for sexual compatibility between isolates of $L$. procerum and $L$. profanum having opposite mating type did not produce ascomata under any of the conditions tested. 


\subsection{Distribution of mating-type genes in a population of L. procerum}

Both mating types were detected in a population of $L$. procerum from the USA. The ratio of MAT1-1 to MAT1-2 was 1:1 for 20 isolates tested (Fig 6). Isolates of opposing mating types were found in close proximity to each other, and in some cases originated from a single beetle gallery.

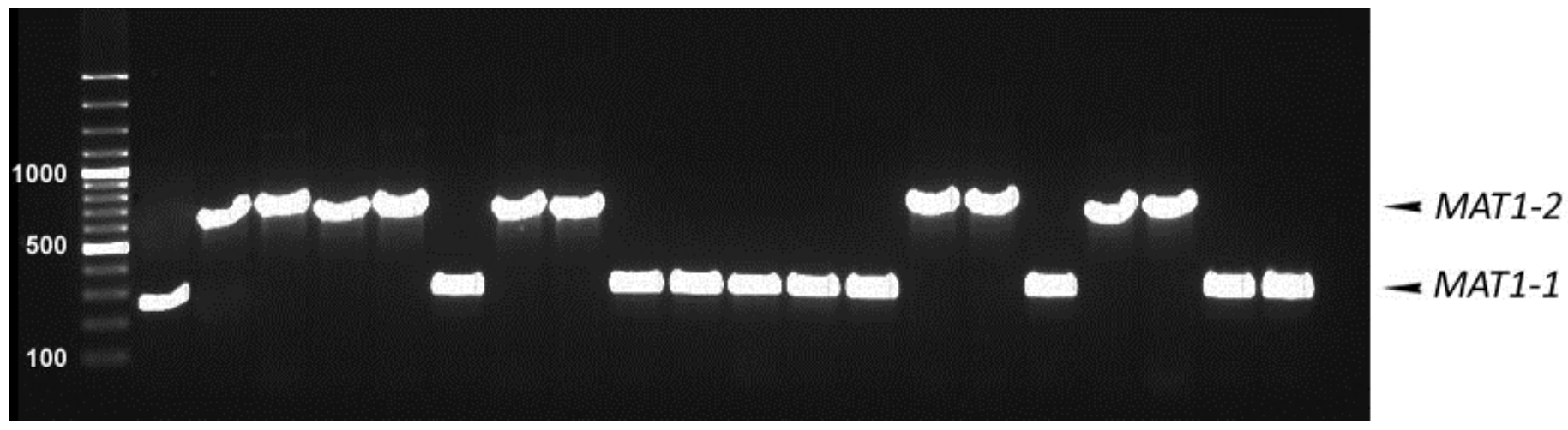

Fig 6 - PCR amplicons resulting from the multiplex PCR (using MAT1-1 and MAT2-1 primers) of a population of $L$. procerum isolates from the USA. The ratio of MAT1-2 and MAT1-2 isolates equivalent to 1:1 infers that sexual reproduction is occurring or has recently taken place within this population. All fragments were separated in $2 \%$ agarose gel, stained with GelRed and visualized under UV light. The molecular weight marker used was GeneRuler ${ }^{\mathrm{TM}} 100$ bp Plus DNA Ladder (Fermentas).

\section{Discussion}

This is the first study to identify and completely characterize the mating type loci in any species of Leptographium. Using robust molecular genetic evidence, both L. procerum and L. profanum were shown to have heterothallic mating systems. This is also the first report describing the complete mating type locus in a heterothallic member of the Ophiostomatales. Together with the MAT1-1 idiomorph from G. clavigera (DiGuistini et al. 2011), partial MAT1-1 and MAT1-2 idiomorphs from O. novo-ulmi (Jacobi et al. 2010; Paoletti et al. 2005), partial MAT1-1 and MAT1-2 idiomorphs from O. quercus (Wilken et al. 2012), the mating type loci characterized in 
this study provide insights into the structure and gene orientation of the mating type locus in the Ophiostomatales.

The MAT1-1 idiomorphs in L. procerum and L. profanum were shown to have very similar sequences and they had a structure typical of those found in other Sordariomycetes, especially those in the Ophiostomatales. The MAT1-1 idiomorphs identified in L. procerum and L. profanum were shown to have three mating type genes i.e. MAT1-1-1, MAT1-1-2 and MAT1-1-3 with similar order and orientation to those of Gibberella fujikuroi, Fusarium oxysporum (Martin et al. 2011; Yun et al. 2000), Cryphonectria parasitica (McGuire et al. 2001), Podospora anserina (Debuchy et al. 1993) and Neurospora crassa (Ferreira et al. 1996). The sequences of MAT1-1 genes in these two fungi are very similar and correspond with those known in other Ophiostomatoid fungi (Table 2). Typical conserved $\alpha$ domains were found in MAT1-1-1 genes of both $L$. procerum and L. profanum, each having one intron in a similar position to that of other Ascomycetes. The nucleotide and amino acid sequences of alpha domains were almost identical for the two species, with only a few differences in the nucleotide sequences and one difference in the amino acid sequence. The predicted amino acid sequences in the alpha domains of $L$. procerum and L. profanum were also very similar to those of O. novo-ulmi subs. novo-ulmi, and somewhat less so to those in F. oxysporum and G. fujikuroi.

In contrast to the MAT1-1 idiomorphs, the MAT1-2 idiomorphs in L. procerum and L. profanum had an atypical structure when compared to those of other ascomycetes. In addition to a mandatory MAT1-2-1 gene, the MAT1-2 idiomorphs in these two species harbor a second ORF that encodes a putative peptide that is highly homologous to the MAT1-1-1 gene product from the MAT1-1 idiomorphs. However, sequence analyses showed that the conserved alpha domain 
was missing, suggesting that these are truncated MAT1-1-1 genes. We were also able to identify the truncated MAT1-1-1 in the MAT1-2 idiomorphs in G. clavigera (GenBank accession number: ACXQ02000048) (DiGuistini et al. 2011) by comparing its sequence with those of L. procerum and L. profanum. The presence of a truncated MAT1-1-1 gene in MAT1-2 idiomorphs in these three species suggests that this organization could be common in some, if not all, Leptographium sensu lato species. Most of the MAT1-2 from other ascomycetes have only MAT1-2-1 gene (Coppin et al. 1997; Turgeon and Yoder 2000). However, similar structures have also been observed in the MAT1-2 idiomorphs of few other heterothallic Sordariomycetes, where pseudogenes, partial sequences, or homologs of MAT1-1 genes are present in the MAT1-2 idiomorph (Kanematsu et al. 2007; Wilken et al. 2012; Yokoyama et al. 2003).

The presence of the truncated MAT1-1-1 in the MAT1-2 locus provides opportunities to study the evolution of the MAT locus in these fungi. Contrary hypotheses on the evolution of homothallism and heterothallism in fungi have been debated for a very long time. Most studies aim to provide arguments and evidence supporting the hypothesis that homothallic fungi evolved from heterothallic ancestors (Gioti et al. 2012; Nygren et al. 2011; Yun et al. 1999). Whereas, only a few others support an opposing hypothesis: that heterothallism arose from homothallism (Amselem et al. 2011; Geiser et al. 1998). The structure of the MAT loci in L. procerum and $L$. profanum, with the presence of a portion of MAT1-1-1 on the MAT1-2 idiomorph, presents possible evidence to address the controversy. However, the data obtained in the present study alone are not adequate to resolve the question. The presence of a portion of the MAT1-1-1 on the MAT1-2 idiomorphs could have resulted from translocation or unequal crossover of MAT1-1 idiomorphs. This concept is often used to explain the evolution of homothallism from heterothallic ancestors. However, it is also possible that the truncated MAT1-1-1 gene resulted 
from incomplete deletions of MAT1-1 genes from the MATI-2 idiomorph, supporting the notion that heterothallism evolved from homothallism. Thorough structure and sequence comparisons of the MAT loci in the heterothallic L. procerum and L. profanum, with other homo- and heterothallic Leptographium sensu lato species will be necessary to fully resolve this question.

Phylogenetic analyses of HMG and $\alpha$ domain amino acid and nucleotide sequences grouped $L$. procerum and L. profanum with other Ophiostomatoid fungi in a distinct clade, separated from other ascomycetes. This suggests that mating type genes could potentially be used to resolve phylogenetic questions in the Ophiostomatales. Mating type genes have been applied in combination with other nuclear genes to resolve phylogenetic relationships and to describe new species (O'Donnell et al. 2004; Turgeon 1998). However, it is widely accepted that reproductive genes are prone to inter-specific gene transfer and this could lead to conflicts with other gene trees. The application of $M A T$ genes as phylogenetic markers should thus be undertaken with care and in conjunction with other gene regions (Inderbitzin et al. 2005; Martin et al. 2011; Paoletti et al. 2006; Strandberg et al. 2010).

Despite many previous efforts to find these structures, the sexual states of $L$. procerum and $L$. profanum remain to be discovered. This is also the case for many other Leptographium species. The heterothallic nature of $L$. procerum and L. profanum, and possibly many other Leptographium species, provides some explanation for the low success rate in mating tests with these fungi. Clearly, the mating process requires the presence of both mating types, which can now be experimentally determined. However, suitable mating conditions are also required and given the complex conditions of bark beetle galleries in which these fungi occur, determining these conditions will remain a challenge. 
Both mating types were present in a natural population of $L$. procerum from the USA, the purported center of origin for this species. This suggests that the potential for genetic recombination exists and that sexual recombination can occur. This also suggests that a sexual state exists for this fungus. The mating type ratio of 1:1 confirms that recombination is occurring frequently. More intensive studies are required to discover the sexual state and to investigate sexual reproduction of these fungi. Knowledge of the mating type loci and the development of PCR based mating type makers in this study will be valuable in the quest for sexual states and to better understand the processes involved in the reproduction of L. procerum and L. profanum.

\section{Acknowledgments}

We thank members of Tree Protection Co-operative Programme (TPCP), the National Research Foundation (NRF), and the University of Pretoria, Pretoria, South Africa, for financial support.

Drs Don Owen and Tom Gordon are thanked for their support in collecting isolates of $L$. procerum and we are grateful to Duong Van Tu for drawing the illustration presented in Figure 1 of this manuscript.

\section{References}

Aljanabi SM, Martinez I, 1997. Universal and rapid salt-extraction of high quality genomic DNA for PCR-based techniques. Nucleic Acids Research 25, 4692-4693.

Amselem J, Cuomo CA, van Kan JAL, Viaud M, Benito EP, Couloux A, Coutinho PM, de Vries RP, Dyer PS, Fillinger S, Fournier E, Gout L, Hahn M, Kohn L, Lapalu N, Plummer KM, Pradier J-M, Quévillon E, Sharon A, Simon A, ten Have A, Tudzynski B, Tudzynski P, Wincker P, Andrew M, Anthouard V, Beever RE, Beffa R, Benoit I, Bouzid O, Brault B, Chen Z, 
Choquer M, Collémare J, Cotton P, Danchin EG, Da Silva C, Gautier A, Giraud C, Giraud T, Gonzalez C, Grossetete S, Güldener U, Henrissat B, Howlett BJ, Kodira C, Kretschmer M, Lappartient A, Leroch M, Levis C, Mauceli E, Neuvéglise C, Oeser B, Pearson M, Poulain J, Poussereau N, Quesneville H, Rascle C, Schumacher J, Ségurens B, Sexton A, Silva E, Sirven C, Soanes DM, Talbot NJ, Templeton M, Yandava C, Yarden O, Zeng Q, Rollins JA, Lebrun M-H, Dickman M, 2011. Genomic analysis of the necrotrophic fungal pathogens Sclerotinia sclerotiorum and Botrytis cinerea. PLoS Genetic 7, e1002230.

Arie T, Christiansen SK, Yoder OC, Turgeon BG, 1997. Efficient cloning of ascomycete mating type genes by PCR amplification of the conserved MAT HMG box. Fungal Genetics and Biology 21, 118-130.

Brewer MT, Cadle-Davidson L, Cortesi P, Spanu PD, Milgroom MG, 2011. Identification and structure of the mating-type locus and development of PCR-based markers for mating type in powdery mildew fungi. Fungal Genetics and Biology 48, 704-713.

Butler G, Rasmussen MD, Lin MF, Santos MAS, Sakthikumar S, Munro CA, Rheinbay E, Grabherr M, Forche A, Reedy JL, 2009. Evolution of pathogenicity and sexual reproduction in eight Candida genomes. Nature 459, 657-662.

Coppin E, Debuchy R, Arnaise S, Picard M, 1997. Mating types and sexual development in filamentous ascomycetes. Microbiology and Molecular Biology Reviews 61, 411-428.

De Beer ZW, Wingfield MJ, 2013. Emerging lineages in the Ophiostomatales, in: Seifert KA, De Beer ZW, Wingfield MJ (eds), The Ophiostomatoid Fungi: Expanding Frontiers. CBS Biodiversity Series 12, Utrecht, The Netherlands. 
Debuchy R, Arnaise S, Lecellier G, 1993. The mat-allele of Podospora anserina contains three regulatory genes required for the development of fertilized female organs. Molecular and General Genetics 241, 667-673.

DiGuistini S, Wang Y, Liao NY, Taylor G, Tanguay P, Feau N, Henrissat B, Chan SK, HesseOrce U, Alamouti SM, Tsui CKM, Docking RT, Levasseur A, Haridas S, Robertson G, Birol I, Holt RA, Marra MA, Hamelin RC, Hirst M, Jones SJM, Bohlmann J, Breuil C, 2011. Genome and transcriptome analyses of the mountain pine beetle-fungal symbiont Grosmannia clavigera, a lodgepole pine pathogen. Proceedings of the National Academy of Sciences of the United States of America 108, 2504-2509.

Ferreira AVB, Saupe S, Glass NL, 1996. Transcriptional analysis of the $m t A$ idiomorph of Neurospora crassa identifies two genes in addition to $m t A-1$. Molecular and General Genetics 250, 767-774.

Fraser JA, Heitman J, 2004. Evolution of fungal sex chromosomes. Molecular Microbiology 51, 299-306.

Geiser DM, Frisvad JC, Taylor JW, 1998. Evolutionary relationships in Aspergillus section Fumigati inferred from partial $\beta$-tubulin and hydrophobin DNA sequences. Mycologia, 831-845.

Gioti A, Mushegian AA, Strandberg R, Stajich JE, Johannesson H, 2012. Unidirectional evolutionary transitions in fungal mating systems and the role of transposable elements. Molecular Biology and Evolution 29, 3215-3226. 
Glass NL, Smith M, 1994. Structure and function of a mating-type gene from the homothallic species Neurospora africana. Molecular and General Genetics 244, 401-409.

Groenewald M, Groenewald JZ, Harrington TC, Abeln ECA, Crous PW, 2006. Mating type gene analysis in apparently asexual Cercospora species is suggestive of cryptic sex. Fungal Genetics and Biology 43, 813-825.

Hawksworth DL, 2011. A new dawn for the naming of fungi: impacts of decisions made in Melbourne in July 2011 on the future publication and regulation of fungal names. IMA Fungus 2, $155-162$.

Inderbitzin P, Harkness J, Turgeon BG, Berbee ML, 2005. Lateral transfer of mating system in Stemphylium. Proceedings of the National Academy of Sciences of the United States of America 102, 11390-11395.

Jacobi V, Dufour J, Bouvet GF, Aoun M, Bernier L, 2010. Identification of transcripts upregulated in asexual and sexual fruiting bodies of the Dutch elm disease pathogen Ophiostoma novo-ulmi. Canadian Journal of Microbiology 56, 697-705.

Jacobs K, Eckhardt LG, Wingfield MJ, 2006. Leptographium profanum sp.nov., a new species from hardwood roots in North America. Canadian Journal of Botany 84, 759-766.

Jacobs K, Wingfield MJ, 2001. Leptographium species: tree pathogens, insect associates and agents of blue-stain. APS Press, St Paul, Minnesota. 
Kanamori M, Kato H, Yasuda N, Koizumi S, Peever TL, Kamakura T, Teraoka T, Arie T, 2007. Novel mating type-dependent transcripts at the mating type locus in Magnaporthe oryzae. Gene 403, 6-17.

Kanematsu S, Adachi Y, Ito T, 2007. Mating-type loci of heterothallic Diaporthe spp.: homologous genes are present in opposite mating-types. Current Genetics 52, 11-22.

Katoh K, Toh H, 2008. Recent developments in the MAFFT multiple sequence alignment program. Briefings in Bioinformatics 9, 286-298.

Kronstad JW, Staben C, 1997. Mating type in filamentous fungi. Annual Review of Genetics 31, 245.

Kück U, Pöggeler S, 2009. Cryptic sex in fungi. Fungal Biology Reviews 23, 86-90.

Linde CC, Zala M, Ceccarelli S, McDonald BA, 2003. Further evidence for sexual reproduction in Rhynchosporium secalis based on distribution and frequency of mating-type alleles. Fungal Genetics and Biology 40, 115-125.

Linnakoski R, de Beer ZW, Duong TA, Niemelä P, Pappinen A, Wingfield MJ, 2012. Grosmannia and Leptographium spp. associated with conifer-infesting bark beetles in Finland and Russia, including Leptographium taigense sp. nov. Antonie Van Leeuwenhoek, 1-25.

Lu M, Zhou X, De Beer Z, Wingfield M, Sun J, 2009a. Ophiostomatoid fungi associated with the invasive pine-infesting bark beetle, Dendroctonus valens, in China. Fungal Diversity 38, 133145. 
Lu Q, Decock C, Zhang X, Maraite H, 2009b. Ophiostomatoid fungi (Ascomycota) associated with Pinus tabuliformis infested by Dendroctonus valens (Coleoptera) in northern China and an assessment of their pathogenicity on mature trees. Antonie Van Leeuwenhoek 96, 275-293.

Martin SH, Wingfield BD, Wingfield MJ, Steenkamp ET, 2011. Structure and evolution of the Fusarium mating type locus: New insights from the Gibberella fujikuroi complex. Fungal Genetics and Biology 48, 731-740.

McGuire IC, Marra RE, Turgeon BG, Milgroom MG, 2001. Analysis of mating-type genes in the chestnut blight fungus, Cryphonectria parasitica. Fungal Genetics and Biology 34, 131-144.

Metzenberg RL, Glass NL, 1990. Mating type and mating strategies in Neurospora. Bioessays 12, 53-59.

Nelson MA, 1996. Mating systems in ascomycetes: a romp in the sac. Trends in Genetics 12, 6974.

Nygren K, Strandberg R, Wallberg A, Nabholz B, Gustafsson T, García D, Cano J, Guarro J, Johannesson H, 2011. A comprehensive phylogeny of Neurospora reveals a link between reproductive mode and molecular evolution in fungi. Molecular Phylogenetics and Evolution 59, 649-663.

O’Donnell K, Ward TJ, Geiser DM, Corby Kistler H, Aoki T, 2004. Genealogical concordance between the mating type locus and seven other nuclear genes supports formal recognition of nine phylogenetically distinct species within the Fusarium graminearum clade. Fungal Genetics and Biology 41, 600-623. 
Paoletti M, Buck KW, Brasier CM, 2005. Cloning and sequence analysis of the MAT-B (MAT-2) genes from the three Dutch elm disease pathogens, Ophiostoma ulmi, O. novo-ulmi and $O$. himal-ulmi. Mycological Research 109, 983-991.

Paoletti M, Buck KW, Brasier CM, 2006. Selective acquisition of novel mating type and vegetative incompatibility genes via interspecies gene transfer in the globally invading eukaryote Ophiostoma novo-ulmi. Molecular Ecology 15, 249-262.

Pöggeler S, Kück U, 2000. Comparative analysis of the mating-type loci from Neurospora crassa and Sordaria macrospora: identification of novel transcribed ORFs. Molecular and General Genetics 263, 292-301.

Ramirez-Prado JH, Moore GG, Horn BW, Carbone I, 2008. Characterization and population analysis of the mating-type genes in Aspergillus flavus and Aspergillus parasiticus. Fungal Genetics and Biology 45, 1292-1299.

Rau D, Maier FJ, Papa R, Brown AHD, Balmas V, Saba E, Schaefer W, Attene G, 2005. Isolation and characterization of the mating-type locus of the barley pathogen Pyrenophora teres and frequencies of mating-type idiomorphs within and among fungal populations collected from barley landraces. Genome 48, 855-869.

Salamov AA, Solovyev VV, 2000. Ab initio gene finding in Drosophila genomic DNA. Genome Research 10, 516-522. 
Scherrer S, Zippler U, Honegger R, 2005. Characterisation of the mating-type locus in the genus Xanthoria (lichen-forming ascomycetes, Lecanoromycetes). Fungal Genetics and Biology 42, 976-988.

Steenkamp ET, Wingfield BD, Coutinho TA, Zeller KA, Wingfield MJ, Marasas WFO, Leslie JF, 2000. PCR-based identification of MAT-1 and MAT-2 in the Gibberella fujikuroi species complex. Applied and Environmental Microbiology 66, 4378-4382.

Stergiopoulos I, Groenewald M, Staats M, Lindhout P, Crous PW, De Wit PJGM, 2007. Matingtype genes and the genetic structure of a world-wide collection of the tomato pathogen Cladosporium fulvum. Fungal Genetics and Biology 44, 415-429.

Strandberg R, Nygren K, Menkis A, James TY, Wik L, Stajich JE, Johannesson H, 2010. Conflict between reproductive gene trees and species phylogeny among heterothallic and pseudohomothallic members of the filamentous ascomycete genus Neurospora. Fungal Genetics and Biology 47, 869-878.

Tamura K, Peterson D, Peterson N, Stecher G, Nei M, Kumar S, 2011. MEGA5: molecular evolutionary genetics analysis using maximum likelihood, evolutionary distance, and maximum parsimony methods. Molecular Biology and Evolution 28, 2731-2739.

Turgeon BG, 1998. Application of mating type gene technology to problems in fungal biology. Annual Review of Phytopathology 36, 115-137.

Turgeon BG, Yoder OC, 2000. Proposed nomenclature for mating type genes of filamentous ascomycetes. Fungal Genetics and Biology 31, 1-5. 
Wilken PM, Steenkamp ET, Hall TA, de Beer ZW, Wingfield MJ, Wingfield BD, 2012. Both mating types in the heterothallic fungus Ophiostoma quercus contain MAT1-1 and MAT1-2 genes. Fungal Biology 116, 427-437.

Wingfield M, Capretti P, Mackenzie M, 1988. Leptographium spp. as root pathogens of conifers. An international perspective, in: Harrington T, Cobb F (eds), Leptographium root diseases on conifers. APS Press, St. Paul, Minnesota, pp. 113-128.

Wingfield MJ, 1986. Pathogenicity of Leptographium procerum and L. terebrantis on Pinus strobus seedlings and established trees. European Journal of Forest Pathology 16, 299-308.

Wingfield MJ, De Beer ZW, Slippers B, Wingfield BD, Groenewald JZ, Lombard L, Crous PW, 2012. One fungus, one name promotes progressive plant pathology. Molecular Plant Pathology 13, 604-613.

Yoder O, Valent B, Chumley F, 1986. Genetic nomenclature and practice for plant pathogenic fungi. Phytopathology 76.

Yokoyama E, Yamagishi K, Hara A, 2003. Structures of the mating-type loci of Cordyceps takaomontana. Applied and Environmental Microbiology 69, 5019-5022.

Yun S-H, Berbee ML, Yoder OC, Turgeon BG, 1999. Evolution of the fungal self-fertile reproductive life style from self-sterile ancestors. Proceedings of the National Academy of Sciences of the United States of America 96, 5592-5597. 
Yun SH, Arie T, Kaneko I, Yoder OC, Turgeon BG, 2000. Molecular organization of mating type loci in heterothallic, homothallic, and asexual Gibberella/Fusarium species. Fungal Genetics and Biology 31, 7-20.

Zipfel RD, De Beer ZW, Jacobs K, Wingfield BD, Wingfield MJ, 2006. Multi-gene phylogenies define Ceratocystiopsis and Grosmannia distinct from Ophiostoma. Studies in Mycology 55, 7597. 